\title{
Gode kort på hånda
}

\author{
Sykepleierstudenter hadde god nytte av pilotprosjekt om utvikling av sykepleieridentitet.
}

D et jobber flere forskjellige yrkesgrupper både på sykehjem og i hjemmetjenesten. Mye av det samme arbeidet utføres av flere yrkesgrupper, og mange sykepleierstudenter sier at de har vanskeligheter med å se sykepleierens særegne kompetanse og rolle. Med utgangspunkt i dette ønsket jeg å undersøke om sykepleieridentiteten kan synliggjøres bedre i utdanningen og hvilke verktøy som kan utvikles og brukes til dette formålet. Prosjektet har som mål å:

, Prøve ut følgekortene som dialogverktøy i veiledningsgrupper.

I Utarbeide følgekort for god sykepleie, med vekt på faglige kunnskaper, praktiske ferdigheter og holdninger, i samarbeid med studentene.

\ Kartlegge muligheten for å kunne videreutvikle et pedagogisk verktøy - eventuelt en metodebok som kan synliggjøre og styrke sykepleieridentiteten i utdanningen.

\section{Positive samtaler}

Hva kjennetegner en god sykepleier og hvilke ferdigheter har en god sykepleier? Hva er sykepleierens særegne kompetanse i forhold til andre helsearbeidere? Dette er noen av flere spørsmål man kan stille seg i forhold til syke-

\section{Hovedbudskap}

Mange sykepleiestudenter opplever at det kan være vanskelig å se sykepleierens særegne kompetanse og rolle i pleie- og omsorgstjenesten. Gjennom prosjektarbeid om sykepleieidentitet kan studentene bl bevisstgjort sin egen yrkesidentitet og dermed være bedre rustet til å møte praksis. Prosjektarbeid er en form for kreativt samspill, og når studentene vektlegger de positive egenskapene hos hverandre, oppstår det relasjoner som gir læring, glede og energi.

\section{Søkeord}

Les mer og finn litteraturhenvisninger på våre nettsider. | Sykepleierolle \Sykepleierutdanning | Identitet I Sykepleier pleieridentitet og den virkelighet studentene møter i praksis.

Anerkjennende studentsamtaler kan være en god metode for å bevisstgjøre studentene og synliggjøre sykepleieridentiteten. Samtalene skal utelukkende ha et positivt fokus (1). Anerkjennende intervju er styrkebasert læring og målet er å utløse det menneskelige potensialet i organisasjoner, stimulere evnen til å tenke nytt om seg selv og evnen til å se nye muligheter (2). Samtalen er sentral. Språket vi bruker vil bevisstgjøre oss og er med på å skape vår virkelighet. Vi skaper hverandre i møter.

Følgekort er et dialogverktøy som kan brukes i samtaler mellom to eller flere personer. Det er et hjelpemiddel til å finne og sette ord på hverandres styrker og gode egenskaper. Målet er å skape større bevissthet om egne og andres sterke sider, og hvordan vi kan ta i bruk disse for å få til ting som er viktige i arbeids- eller utdanningssammenheng (1).

\section{Følgekort}

En kortstokk består av 24 forskjellige kort, og hvert kort beskriver en positiv egenskap ved en person eller et moralsk mål. I tillegg finnes det blanke kort som deltakerne eller studentene skal bruke til å skrive ned den personlige positive egenskapen som utkrystalliserer seg gjennom samtalen. Det finnes moralske mål, eller dyder, som alle mennesker strever etter på tvers av kulturer (1). Seks slike moralske mål er: Klokskap, mot, medmenneskelighet, rettferdighet, måtehold og transendens. Man tenker seg at det er det enkelte menneskets karakterstyrke som gjør det mulig å realisere disse moralske handlingene. Mennesket setter de moralske handlingene ut i live ved hjelp av sin personlige styrke. Ved å bruke følgekortene får studentene mulighet til å gjøre seg kjent med dette begrepsapparatet.

\section{Kreativt samspill}

Gruppearbeid, gruppesamtaler, idédugnad og prosjektarbeid er kreative former for samspill. Gjennom dette opplever mennesker kontakt og fellesskap. Når mennesker skaper noe sammen, oppstår det bånd mellom dem som gir glede og energi. I boken Relasjonskompetanse skriver Jan Spurkeland (4) at det overføres og skapes en kraft mellom gruppedeltakerne som er selvfornyende og varig. Denne kraften har sitt utspring i godhet for hverandre. Gleden er gjensidig og oppleves som medfølelse, forståelse, harmoni, raushet, åpenhet, sympati, aksept og personlig styrke og motivasjon. Dette vil være erfaringer og verdier som studentene kan bære med seg ut i praksis.

\section{Sykepleieridentitet}

I hverdagen bekreftes det enkelte mennesket av de andre, og slik utvikles identitet og yrkesidentitet. Mennesket har behov for trygghet, tilhørighet, anerkjennelse og forutsigbarhet for å kunne utvikle og vedlikeholde sin identitet og yrkesidentitet. Mangel på bekreftelse kan oppleves som en trussel mot vår yrkesidentitet. Vår yrkesidentitet er knyttet til våre muligheter for yrkesutøvelse. Bevisstgjøring og synliggjøring av sykepleieridentiteten i utdanningen vil kunne bidra til at studentene er bedre rustet til å møte praksis.

En god sykepleier skal ha gode og forsvarlige fagkunnskaper, gode praktiske ferdigheter og «bærende» yrkesetiske holdninger. I tillegg må han eller hun ha kunnskaper, holdninger og vilje til å utøve faglig skjønn. Kari Martinsen skriver i sin bok Fra Marx til Løgstrup (3) følgende: «Det faglige skjønn er knyttet til det konkrete. Skjønnet uttrykker fagkunnskapen gjennom de naturlige sanser. Med sin åpenhet for sansingen gir skjønnet mulighet for at sykepleieren kan ta imot pasientuttrykket og tolke og strukturere uttrykkene for det gjennom ferdigheter og grep, holdning og handling, slik at pasienten opplever situasjonen som god».

\section{Pilotprosjekt}

Pilotprosjektet varte i 16 uker og ble gjennomført da studentene hadde praksis i hjemmesykepleien og sykehjem. Tolv studenter fra to ulike kull deltok, studenter fra desentralisert 
og nettbasert utdanning. Gruppeprosessen, samhandlingen, kreativiteten og fellesskapet var like viktig som arbeidsresultatet. En student uttrykte det slik: «Det har vært godt med veiledningsgrupper. Lærerikt å høre hvordan de andre har opplevd praksis. Godt å snakke med andre i samme situasjon. Jeg har fått hjelp til oppgaver, og det har vært veldig sosialt». Studentene hadde tre gruppesamlinger der de arbeidet med følgekort.

\section{Første gruppesamling}

På første gruppesamling informerte jeg om styrkebasert læring og bruk av følgekort. Deretter delte jeg studentene inn i grupper på to og to som gikk sammen om følgende oppgave: «Fortell om noe du har fått til i arbeidet eller praksisen som du er særlig stolt av, en situasjon der du viser 〈deg på ditt beste〉. En situasjon som viser noe du er stolt av å ha fått til eller gjort. Det kan være en situasjon der du opplevde «at alt klaffet> eller følte en dyp glede over det du holder på med.» Den ene forteller og den andre lytter. Det er ikke lov å avbryte, men lytte og registrere og vise den andre oppmerksomhet. Hver deltaker forteller i noen minutter, så byttes rollene.

Etter at studentene har fortalt sin historie, skal de bruke følgekortene. Hver deltaker skal ta utgangspunkt $\mathrm{i}$ den andres historie og ved hjelp av kortene finne fram til tre positive egenskaper hos medstudenten. Tre følgekort som illustrerer disse egenskapene skal plukkes ut fra kortstokken. Når de tre følgekortene er valgt ut, presenteres de for hverandre. Det er viktig at man leser opp det som står på kortet og forklarer hvorfor akkurat denne egenskapen er valgt. De tre følgekortene leveres til den andre. Mottakeren skal selv få velge ut et av de tre kortene han eller hun føler seg mest vel med, og fortelle hvordan han eller hun opplever denne formen for tilbakemelding. Her forteller studentene hverandre hvordan de opplever positive tilbakemeldinger og bekreftelser på atferd, kunnskaper og holdninger.

I løpet av første gruppesamling sa noen av studentene at det burde være noen følgekort som handlet mer spesifikt om sykepleie. Vi snakket litt om det i gruppen, og studentenes oppdagelse og utsagn førte oss lett over i neste fase av prosjektarbeidet som nettopp var å utarbeide sykepleiekort.

\section{Andre gruppesamling}

Jeg hadde en kort oppsummering fra forrige samling. Deretter ble studentene delt inn i grupper på fire. De fikk følgende oppgave: «Ta utgangspunkt i en situasjon fra praksis som en av studentene forteller. Det kan være en situasjon fra første gruppesamling. Finn ferdigheter hos vedkommende ved hjelp av følgekortene.»

Denne prosessen danner overgang til neste trinn som består av å finne gode sykepleieegenskaper i de praksissituasjoner som studentene erfarer og forteller om. Spørsmålet blir da: Hva kjennetegner en god sykepleier? Hvilke egenskaper bør en sykepleier ha når det gjelder:

, Faglige kunnskaper

, Praktiske ferdigheter

, Yrkesetiske holdninger

Følgekortene som vi tok utgangspunkt i handlet om moralske mål (dyder), og det var nok årsaken til at studentene først diskuterte yrkesetikk og holdninger. Studentene diskuterte og kom med forslag til hva som burde stå på sykepleiekortene. Sykepleiekort med overskriften holdninger begynte å ta form. Jeg systematiserte forslagene fra gruppene under de tre sykepleieegenskapene. Dette ble et utkast til sykepleiekort. Vi skulle arbeide videre med dem på neste samling og evaluere prosjektarbeidet.

\section{Tredje gruppesamling}

Først delte jeg ut utkastene til sykepleiekort til hver enkelt og sa litt om arbeidet så langt. Jeg ga studentene positive tilbakemeldinger og anerkjennelse, både på vilje til deltakelse og engasjement. Noen av sykepleiekortene hadde fått mange punkter, mens andre sykepleiekort kun hadde overskrift. På denne gruppesamlingen skulle studentene ha muntlig fremlegg av studiekrav, noe som var en individuell oppgave. Studentene fikk i oppgave å gi sine medstudenter tilbakemeldinger på fremlegget ut fra sykepleieregenskaper de mener er viktige. Disse ble skrevet inn i kortene. Utkastene til sykepleiekort fra forrige

GODE KORT: Ved hjelp av dialogverktøyet følgekort får sykepleierstudentene hjelp til å sette ord på hverandres sterke sider og positive egenskaper. Foto: Scanpix.

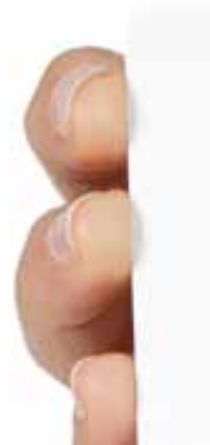

gruppesamling ble fulgt opp og videreutviklet i samspill mellom studenter og lærer.

\section{Studentevalueringer}

Studentene ga individuelle og anonyme tilbakemeldinger på eget evalueringsskjema om hvordan de opplevde gruppeprosessen, prosjektarbeidet, arbeidsmetoden, innholdet, nytteverdien og ønsket om å fortsette. Ti av tolv studenter svarte. Evalueringen viste at studentene opplevde gruppeprosessen som stimulerende, støttende, motiverende og at samspillet i gruppene var preget av gjensidig tillit og respekt. På en skala fra 1-6, der 6 er høyeste skår, ligger hovedvekten (90 prosent) av svarene på 5 og 6 .

Hvordan gruppearbeidet hadde fungert ble vurdert som godt og svært godt av samtlige. Innhold og tema ble vurdert som aktuelle og svært aktuelle. En student sa: «Man lærer av å høre hva de andre skriver om og hvordan». Nytteverdien samlet sett ble vurdert som stor for 75 prosent av studentene. Åtte av ti studenter svarte at gruppearbeidet har bidratt til bevisstgjøring i forhold til sykepleieridentitet. En student sa: «Jobbingen med kortene fører til refleksjon over hvilke av sykepleierens oppgaver som er viktige, og hva som forventes av kunnskap i sykepleiefaget». Svarene viste at samtlige studenter ønsket å fortsette med gruppearbeid, og at de kunne tenke seg å delta $\mathrm{i}$ et videre prosjektarbeid om sykepleieridentitet.

\footnotetext{
LITTERATUR

1. Hauger B. Metodebok - Opplæringsprogram i prosessledelse. Buskerud: S

areptas AS., 2010.
. Hauger B. Organisasjoner som begeistrer. Oslo: Kommuneforlaget AS., 2008 . 3. Martinsen K. Fra Marx til Løgstrup. Otta: TANO AS, 1997.

Spurkeland J. Relasjonskompetanse. Oslo: Universitetsforlaget AS, 2010.
} 